Borneo Journal of Sciences \& Technology, Volume (3), Issue (1), Pages: 34-42

DOI: http://doi.org/10.3570/bjost.2021.3.1-06

e-ISSN: 2672-7439

(C) 2018, UCTS Publisher.

Submitted: $15^{\text {th }}$ September $2020 \quad$ Accepted: $03^{\text {rd }}$ November $2020 \quad$ Published: $31^{\text {st }}$ January 2021

\title{
Gold Potential and Structural Analysis of Bedrock Depth for Sustainable Mining in Batu Melintang, Kelantan
}

\author{
Mohd Syakir Sulaiman, Wani Sofia Udin and Aweng A/l Eh Rak \\ Geoscience Department, Faculty of Earth Science, University Malaysia Kelantan (UMK), \\ 17600 Jeli, Kelantan, Malaysia.
}

\begin{abstract}
Batu Melintang is a well-known high potential gold deposit zone as it is located within the Bentong-Raub suture zone. The study area is also known as a highly potential alluvium placer deposit as so many traditional miners are panning along Pergau River and abandoned mines detected. There are still so few studies being conducted on the hard rock to understand the gold source. This study was conducted to map out the geology of the zone with high gold mineralization occurrence and to investigate the bedrock depth for further assessment of environmental suitability for the location to be mined. Geological mapping was conducted to obtain samples from divided 20 grids with a total of 140 samples were taken and tested by using fire assay with atomic absorption spectrometry finish (FA-AAS). A total of 27 out of 140 samples show high potential gold intensity higher than $0.01 \mathrm{ppm}$. The highest gold intensity detected on the northern and southwestern part of the study area. Then, a geophysical survey is conducted using Electrical Resistivity Imaging method to assess the depth of the potential mining zone in the subsurface. The geophysical survey shows that the average depth of the potential layer is about $7 \mathrm{~m}$ and at that depth, the environmental impact cannot be avoided easily. Further mining plan or activity would require detailed assessment of the environmental impact because most of the potential mineable zones are located deep and close to Pergau River, which is the main water source of Jeli area.
\end{abstract}

Keywords: Gold, Quartz vein, Geological mapping, Fire assay, Batu Melintang.

\section{INTRODUCTION}

The high potential gold deposit is well-known in Batu Melintang. Goh et al., [1] stated Batu Melintang was part of the gold zone or gold-silver-mercury zone due to the presence of low sulphide quartz veins. These low sulphide quartz vein that formed along the shear zones of granitoid bodies can be found at Batu Melintang area [1]. According to Ariffin [2], most of the gold is mined from quartz lode and stockwork deposits which are related to the accretionary prism along the terrain boundary known as the Raub-Bentong Suture. Batu Melintang is also included in Bentong-Raub suture zone, thus the gold mining activity is supposedly taking place by considering the gold deposit on hard rock sources compared to current activity of gold mining on alluvium placer deposit sources.

This study was done by focusing on the resource of gold deposit on the hard rock. Determination of the intensity of gold deposit on the hard rock sources was done to observe and study the location of high intensity gold deposit. The intensity of gold deposit on the hard rock was conducted by using geochemical method of
Fire Assay and followed by atomic absorption spectrometry (AAS) method. The results of gold deposit intensity then further studied by relating to the depth of subsurface hard rock. There is potential gold mining on hard rock sources in the future due to the presence of gold deposit on the hard rock. Hence, by concerning the depth of subsurface bedrock, the assessment of environmental effects before mining activities can be properly done.

The depth of bedrock is discovered through a geophysical survey. The popular method in geophysical survey is electrical resistivity imaging (ERI) which is well-known for its effectiveness for mineral exploration [3]. ERI survey is also an environment-friendly technique as it is a non-destructive method that can reduce the disruption and damage to the site $[3,4]$. The ability of resistivity survey to display the subsurface resistivity value enable the determination of subsurface bedrock. The bedrock depth is measured and interpreted from the produced pseudosection image. The information of bedrock depth is one of important factors to take account in the environmental assessment and the planning of mining activities. This study is vital

Corresponding Author: Mohd Syakir Sulaiman, Universiti Malaysia Kelantan (UMK),

Email: syakirsulaiman123@gmail.com 
in providing the location of high intensity gold deposit and depth of bedrock for environmental assessment in term of lowering the environmental effects and also reducing the reducing the mining site destruction.

\section{MATERIALS AND METHODS}

\section{Study Area}

The study was conducted at Batu Melintang, Jeli District, Kelantan. The lithology of the study area consists of gneiss, schist and metasediment with N-S trending of granitic intrusion.The geological map of Batu Melintang is attached in Appendix 1. The Mangga Formation and Telong Formation were made up by metamorphic sequences of arenaceous, argillaceous, pyroclastic, calcareous and schistose rocks [5]. The study area also was located within the Bentong- Raub Suture Zone and also part of Central Gold Belt. The study area was divided into 20 grids for systematic sample collecting. Figure 1 shows the map of the study area and the location of the survey line.

\section{Sample Collection and Analysis}

By traversing in the study area, geological data were recorded and sampling was done. 140 samples were collected through the inventory method of 20 grids in the study area. The characteristic of rock chosen for the study was an exposed hardrock with visible veins structures. The samples were prepared and crushed into fine-powder which then were tested for their gold intensity by using the geochemical method.

The methods used are conventional method for gold detection used for geochemical analysis which are Fire Assay with Atomic Absorption Spectrometry finish (FA-AAS) method. Fire assay is used to separate the gold from basic metal. Then, AAS measures the concentrations of gold by using the wavelengths of light absorbs by the gold. The detection limit for this method is $0.01 \mathrm{ppm}$ for lower detection, and $1000 \mathrm{ppm}$ for upper detection limit.

\section{Geophysical Survey}

The geophysical survey was carried out in the study area by using ERI method. This method was done to measure the depth of the potential mining zone in the subsurface. Ten survey lines were conducted; each survey line was conducted at a different location. The locations of this survey were chosen based on the presence of gold intensity in the area. One survey line for each grid which contains gold intensity higher than 0.01 part per million ( $\mathrm{ppm})$. The total length of each survey line was 200/400 metres with several configuration arrays used such as Wenner, Pole-Dipole and Schlumberger. The data acquisition was done by injecting the electric on the ground surface to measure the resistivity value of subsurface materials. The data obtained in the field was further processed by using RES2DINV software to produce the resistivity pseudosection of the subsurface. The pseudosection was then interpreted to determine the depth of subsurface bedrock present in the area.

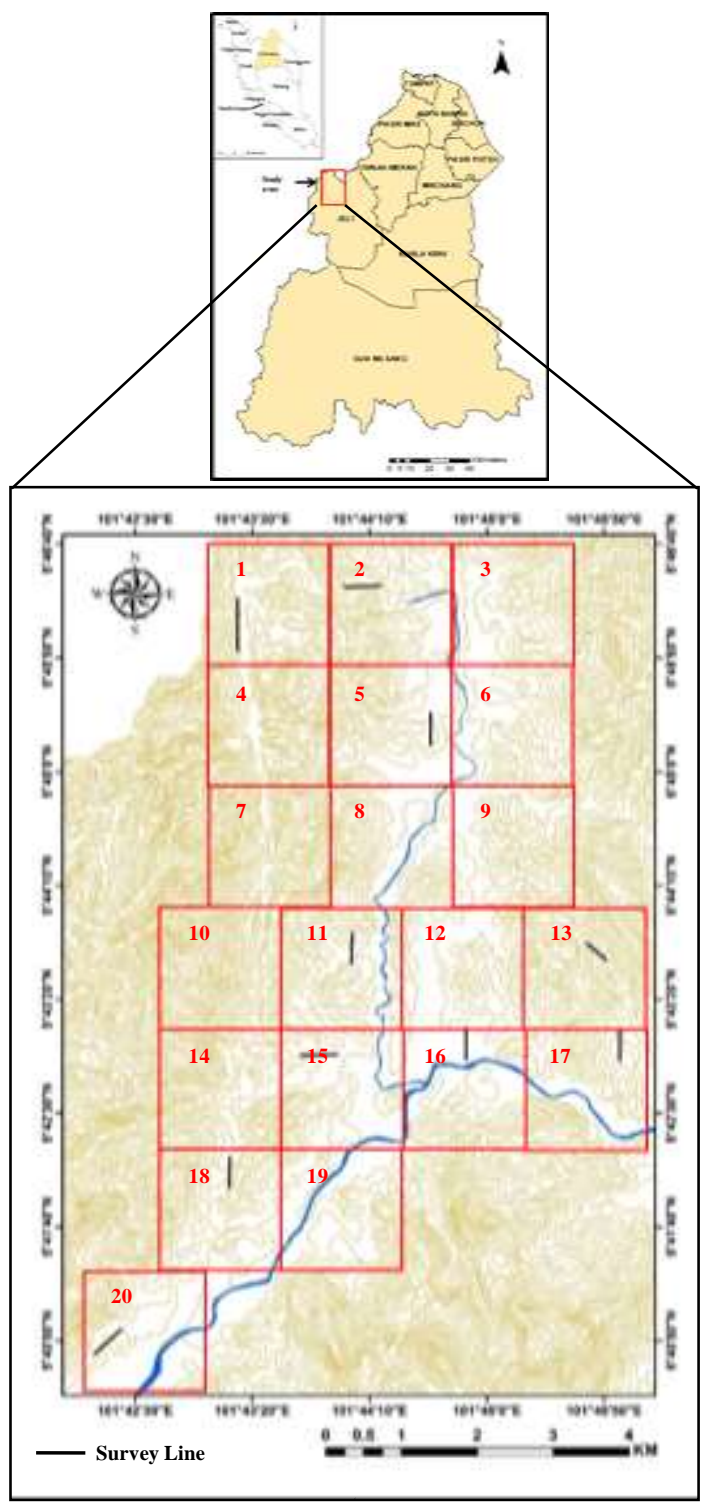

Figure 1: Map of study area and location of survey lines

\section{RESULTS AND DISCUSSION}

A hundred and forty samples were chosen and processed by fire assay and follow-up AAS method and 27 samples consist of high gold intensity. The results of gold intensity in the study area were presented in Figure 2. From the results, the intensity of gold in the study 
area was mapped out as shown in Figure 3. It is found that the high gold intensity area is distributed at the northern and southwestern part of the study area. The highest intensity values of gold, $0.47 \mathrm{ppm}$ is detected at the northern part of study area (Grid 2) which located at an active gold mining present in a small-scale. Most of the rock sample contains gold deposit is in quartz vein. Another location of high values of gold deposit is found at the southwestern part of the study area (Grid 20) with a range of gold value between $0.28-0.31 \mathrm{ppm}$. The chart in Figure 2 showed the range of high gold intensity in the area was between $0.3-0.47$ ppm. Further study on the gold intensity and its connectivity with the depth of bedrock was done through subsurface structural analysis.

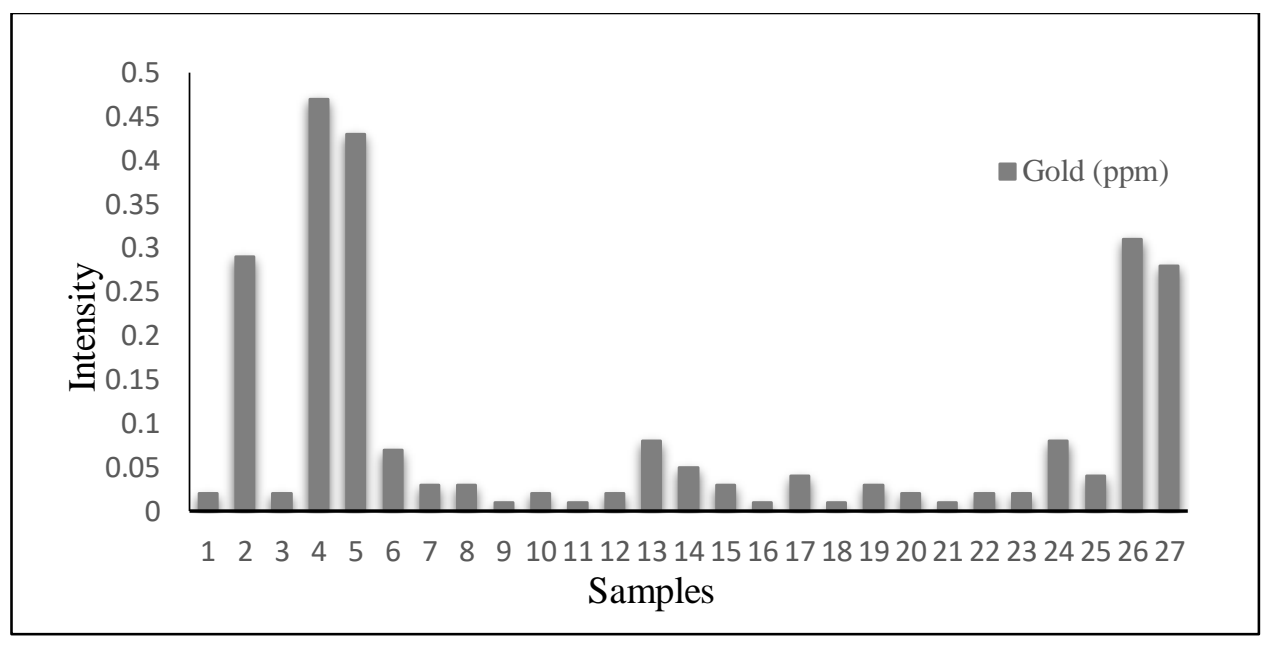

Figure 2: Intensity of gold for each detected sample

Analysis of subsurface structure was conducted by using the ERI method. The subsurface structure included bedrock was revealed in the pseudosection images. The depth of bedrock was determined by interpreting the resistivity pseudosection profiles produced by the RES2DINV software.

Classifications of bedrock and shear/weak zone were done through interpreting the resistivity values. The low resistivity area (resistivity values $<1000 \Omega \mathrm{m}$ ) was classified as shear /weak zone or overburden layer; while the high resistivity area (resistivity values $>1000 \Omega \mathrm{m}$ ) was classified as bedrock. In pseudosection, the blue to orange colours represent fractured zone; red to purple colours represent bedrock. However, the presence of fractured zone was not significant for this study.

Ten survey lines were conducted in the study area with 200 meters length; one survey line represents each grid. The pseudosection profile produced for each survey line is presented in Appendix 2. The results displayed a depth of penetration for the subsurface imaging was ranging from 0 to $30 / 50$ meters. Interpretation of bedrock depth was done in each survey line based on its high resistivity value. Maximum depth of bedrock can be detected in the pseudosection up to 50 meters.

Based on the results in Table 1, it appeared the average minimum depth of subsurface bedrock were ranging from $0 \mathrm{~m}$ to $25 \mathrm{~m}$. The bedrocks depth in the study area were varied for each location. The results indicated the bedrocks in the study area were quite at a deep level from the surface. The deepest bedrock detected is at a depth of 25 meters from the ground surface which situated at Grid 1, 5,13,15,16 and 17. Most of subsurface bedrock in the study area has high depth of more than $20 \mathrm{~m}$. There was also bedrock located near or at the surface identified in Grid 2 and Grid 18. The grid with high gold intensity displayed a moderate to high depth of bedrock ranging from $5 \mathrm{~m}$ to $15 \mathrm{~m}$ which mean large excavation is needed to reach the bedrock layer to exploit the gold deposit at these location.

Table 1 showed the overall results of gold intensity and depth of bedrock within each grid. The results were interpreted as the gold intensity of an area does not influence by the depth of subsurface bedrock or vice versa. 
Gold Potential and Structural Analysis of Bedrock Depth for Sustainable Mining in Batu Melintang, Kelantan

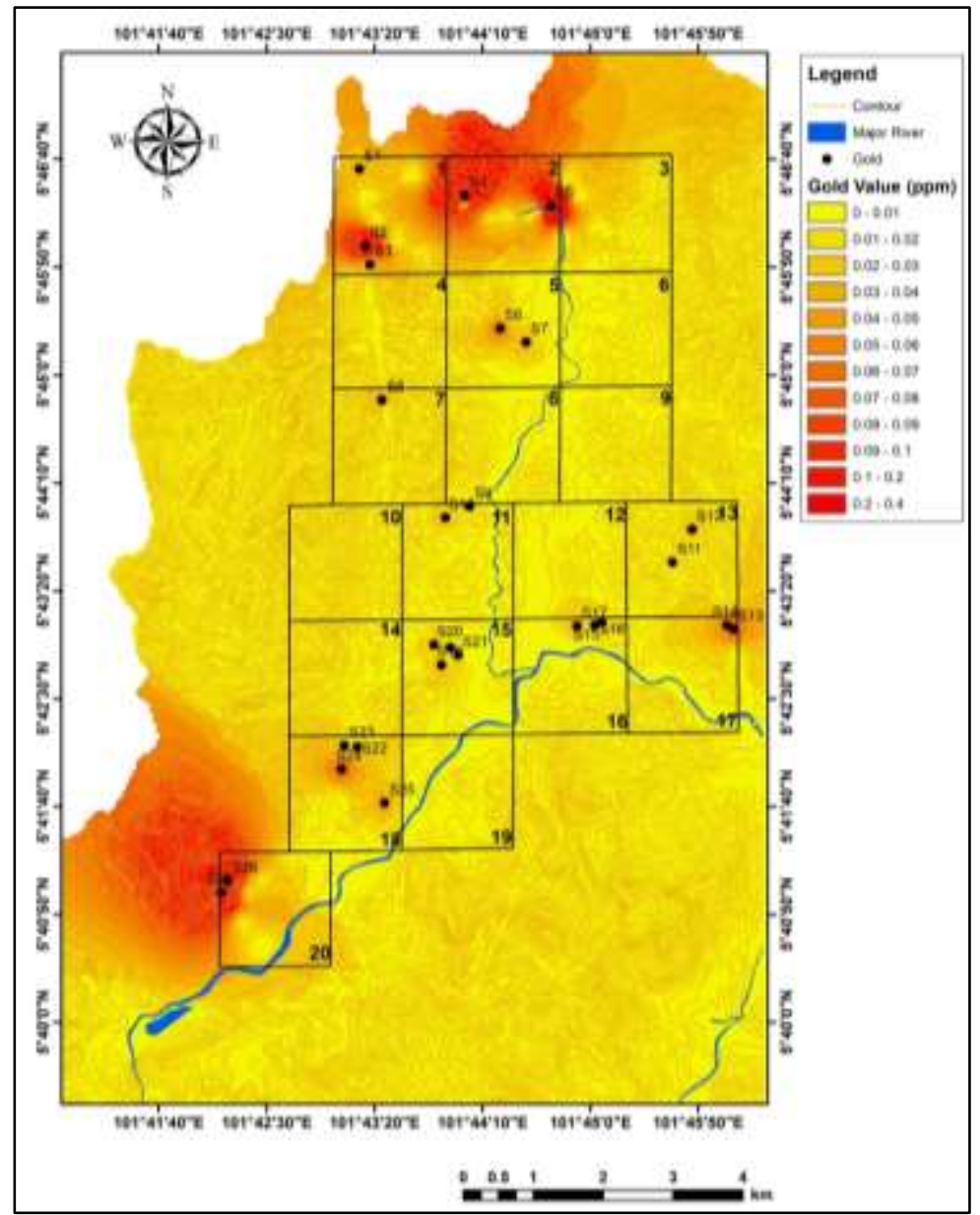

Figure 3: Map of gold intensity in the study area

Table 1: The result of gold intensity and depth of bedrock for each grid

\begin{tabular}{|c|c|c|}
\hline Grid & Gold intensity (ppm) & $\begin{array}{c}\text { Average minimum depth } \\
\text { of bedrock (m) }\end{array}$ \\
\hline 1 & 0.02 & 20 \\
\hline 2 & 0.47 & 5 \\
\hline 5 & 0.05 & 25 \\
\hline 11 & 0.02 & 10 \\
\hline 13 & 0.01 & 20 \\
\hline 15 & 0.02 & 20 \\
\hline 16 & 0.03 & 25 \\
\hline 17 & 0.07 & 25 \\
\hline 18 & 0.04 & 0 \\
\hline 20 & 0.31 & 15 \\
\hline
\end{tabular}

\section{CONCLUSION}

The results of geochemical analysis indicated that the gold potential area on hardrock source was widely distributed in Batu Melintang. However, there is no specific study done on gold deposit on hard rock in this area. The high gold intensity area was found in several places in the study area; an area within Grid 2 and Grid 20. Most of the detected samples had a value ranging 
Gold Potential and Structural Analysis of Bedrock Depth for Sustainable Mining in Batu Melintang, Kelantan

from 0.05 to $0.01 \mathrm{ppm}$ whereas the highest gold intensity detected was $0.47 \mathrm{ppm}$.

The subsurface bedrocks in the study area were located at the deep level of depth which ranging from 0 to 25 meters from the surface. This range values of bedrock depth is considered as a high depth up tp 25 meters. Despite that, there is no relationship between gold intensity and depth of subsurface bedrock. The bedrocks depth also varied within the study area with an average of $7 \mathrm{~m}$ depth. At this depth, the exploitation of gold deposit will give impact to the surrounding environmentas due to large-scale of excavation are required to obtain the deep layer of potential zone.

Hence, an effective, detailed and proper environmental assessment is required to be done before proceeding with the mining activities of the gold exploitation on hard rock source.

\section{ACKNOWLEDGMENT}

The authors would like to express gratitude to Universiti Malaysia Kelantan for equipment and support in this research.

\section{REFERENCES}

[1] Goh, S. H., Teh G.H. \& Wan Fuad Wan Hassan, 2006. Gold Mineralization and Zonation in the State of Kelantan Abstract: Gold mineralization in Kelantan. Geological Society of Malaysia Bulletin 52, June 2006, 129-135.

[2] Ariffin, K.S., 2012. Mesothermal lode gold deposit Central Belt Peninsular Malaysia.Earth Sciences. ISBN:978-953-307-861-8.

[3] Bery, A. A., \& Saad, R. (2012). Clayey sand soil's behaviour analysis and imaging subsurface structure via engineering characterizations and integrated geophysical tomography modelling methods. International Journal of Geosciences, 3(01), 93.

[4] Azhar A T S, Hazreek Z A M, Aziman M, Haimi D S, and Hafiz Z M 2016 Acidic barren slope profiling using electrical resistivity imaging (ERI) at Ayer Hitam area Johor, Malaysia. In Journal of Physics: Conference Series 710 1-9.

[5] MT-JGSC (Malaysia - Thailand Border Joint Geological Survey Committee) 2006 Geology of the Batu melintang - Sungai kolok transect area along the Malaysia-Thailand border. Minerals and Geoscience Department Malaysia and Department of Mineral Resources, Thailand 1-70 
Gold Potential and Structural Analysis of Bedrock Depth for Sustainable Mining in Batu Melintang, Kelantan

Appendix 1

APPENDIX

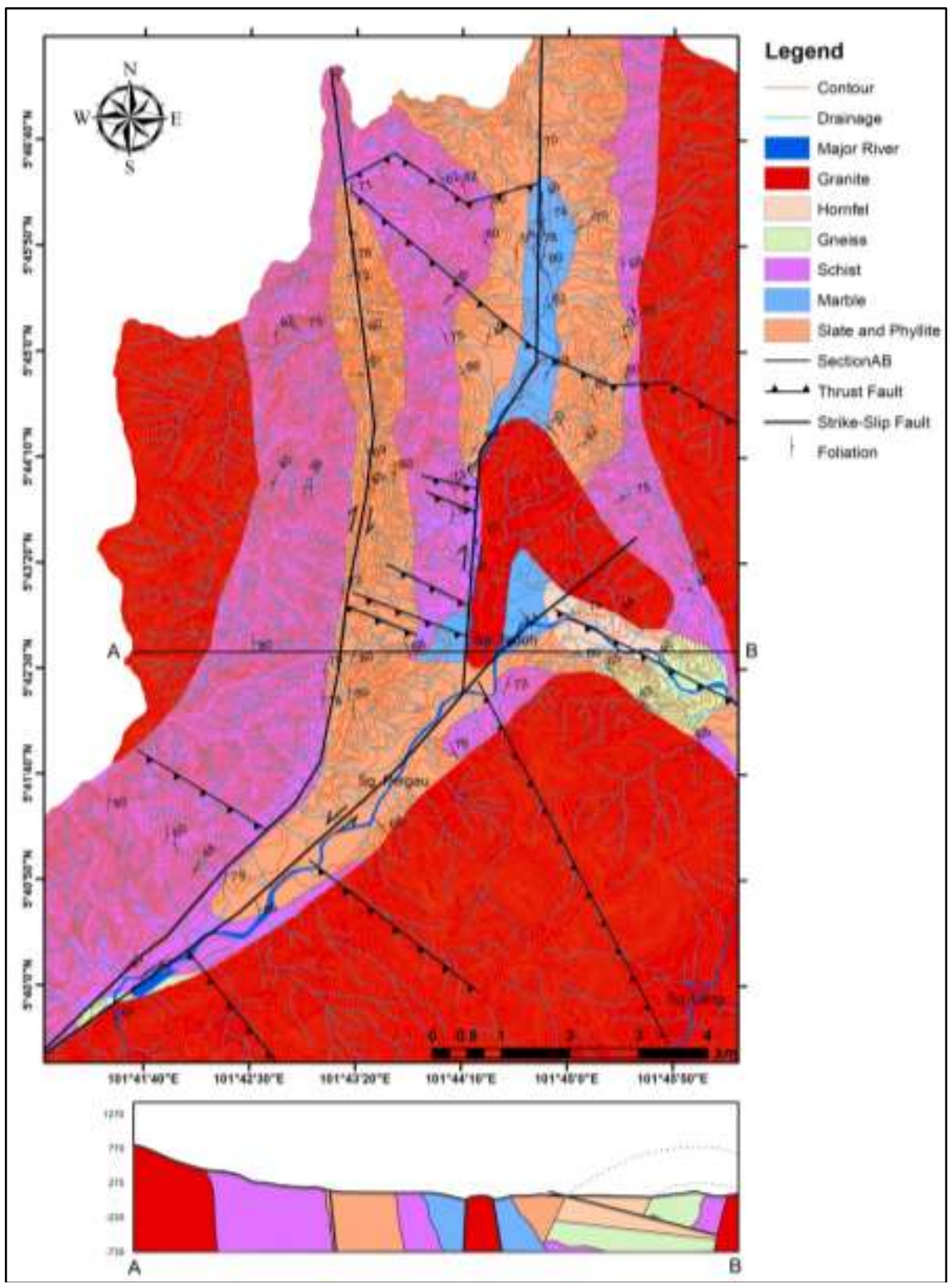

Geological Map of Batu Melintang 
Gold Potential and Structural Analysis of Bedrock Depth for Sustainable Mining in Batu Melintang, Kelantan

\section{Appendix 2}

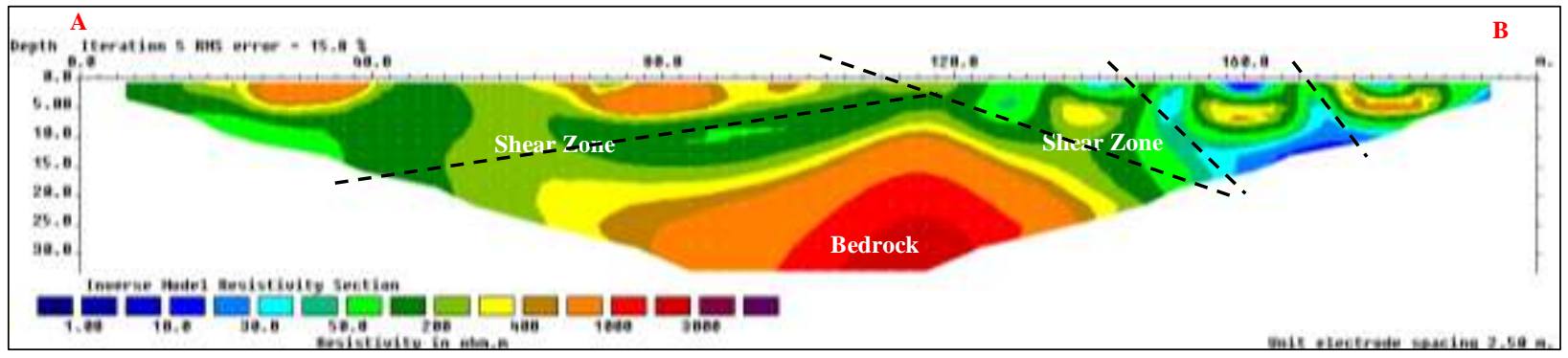

Survey Line 1 in Grid 1

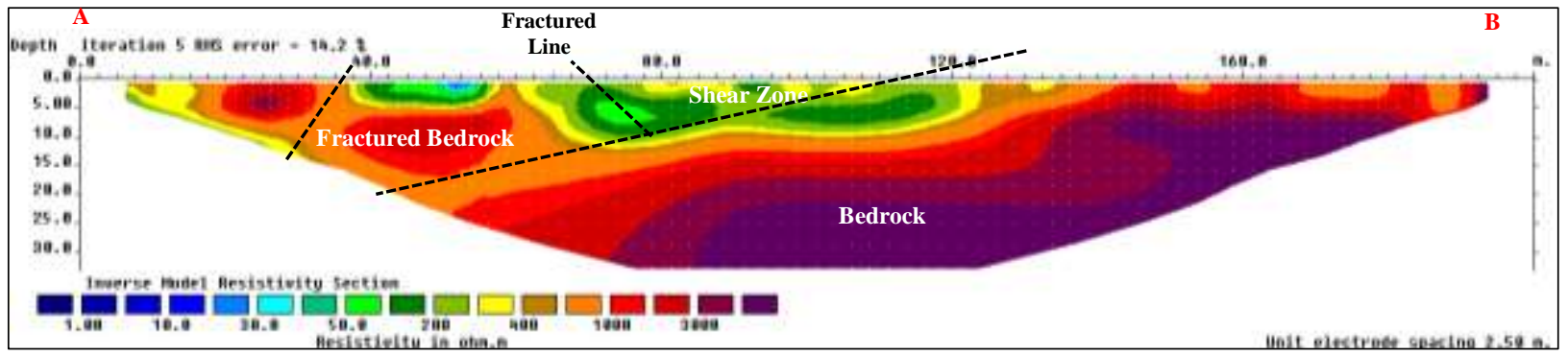

Survey Line 2 in Grid 2

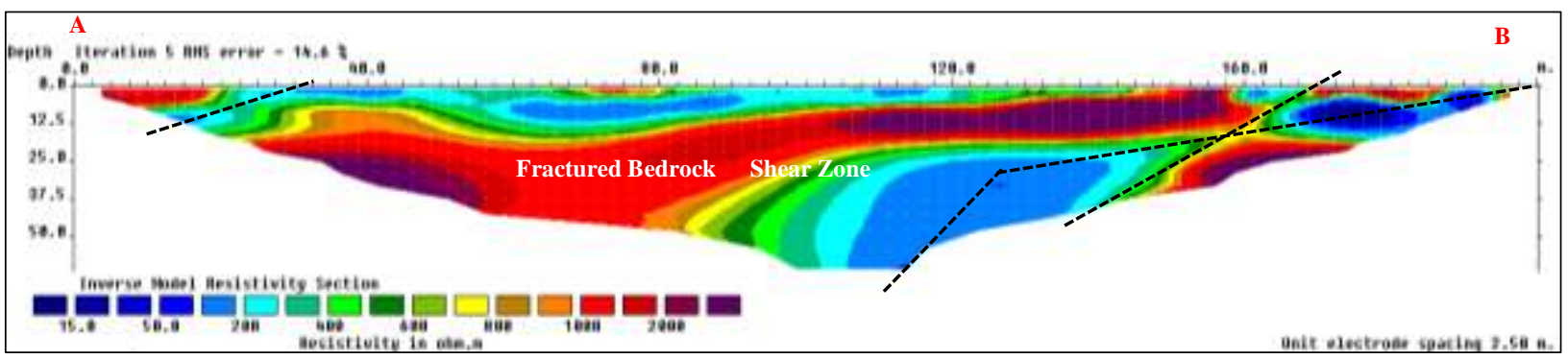

Survey Line 3 in Grid 5

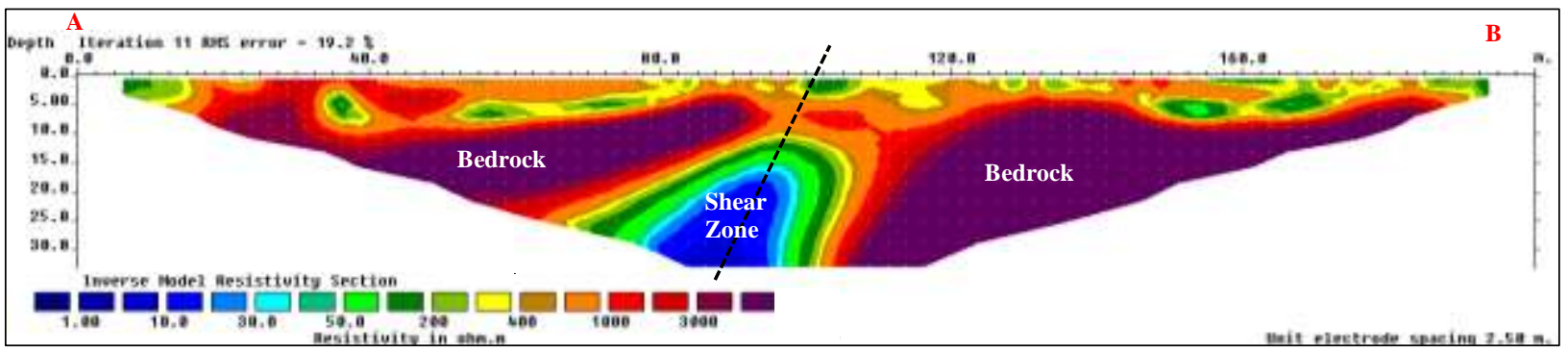

Survey Line 4 in Grid 11 
Gold Potential and Structural Analysis of Bedrock Depth for Sustainable Mining in Batu Melintang, Kelantan

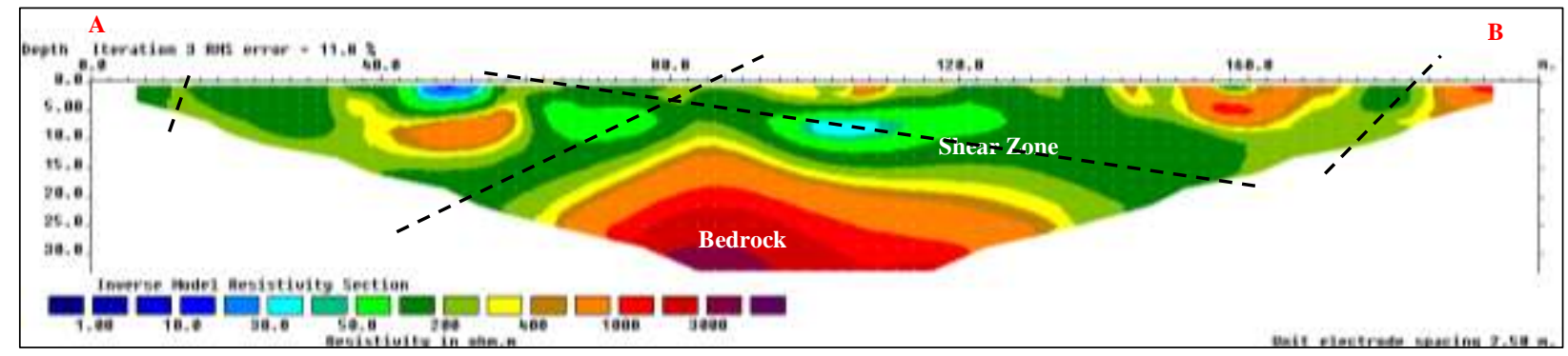

Survey Line 5 in Grid 13

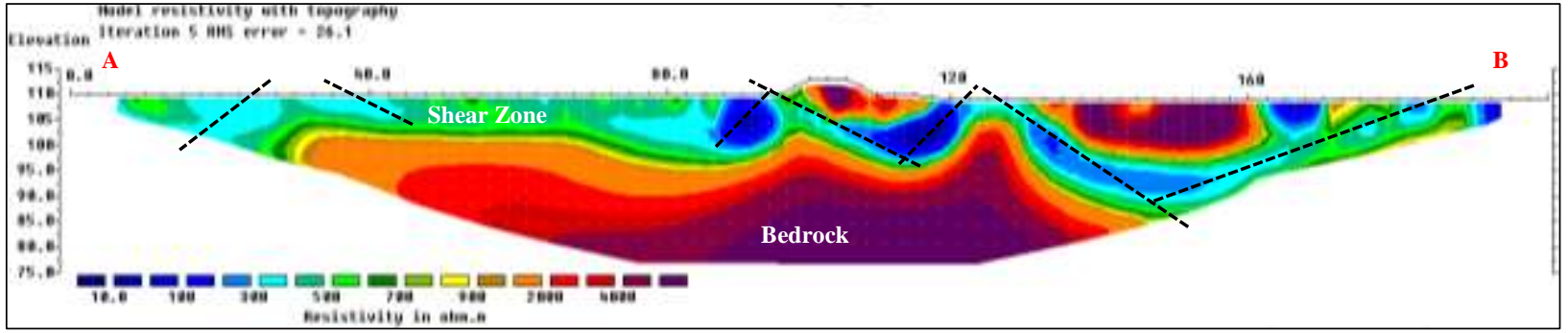

Survey Line 6 in Grid 15

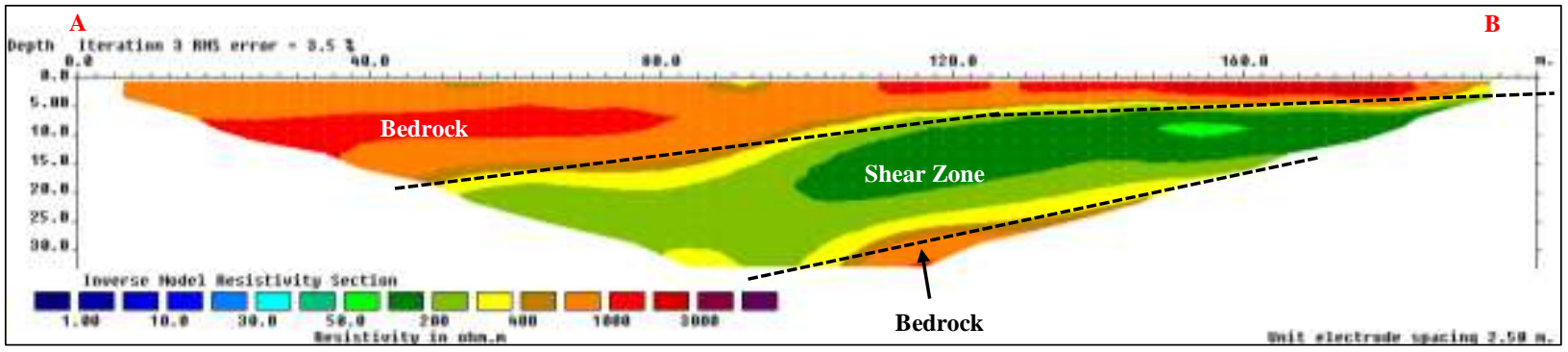

Survey Line 7 in Grid 16

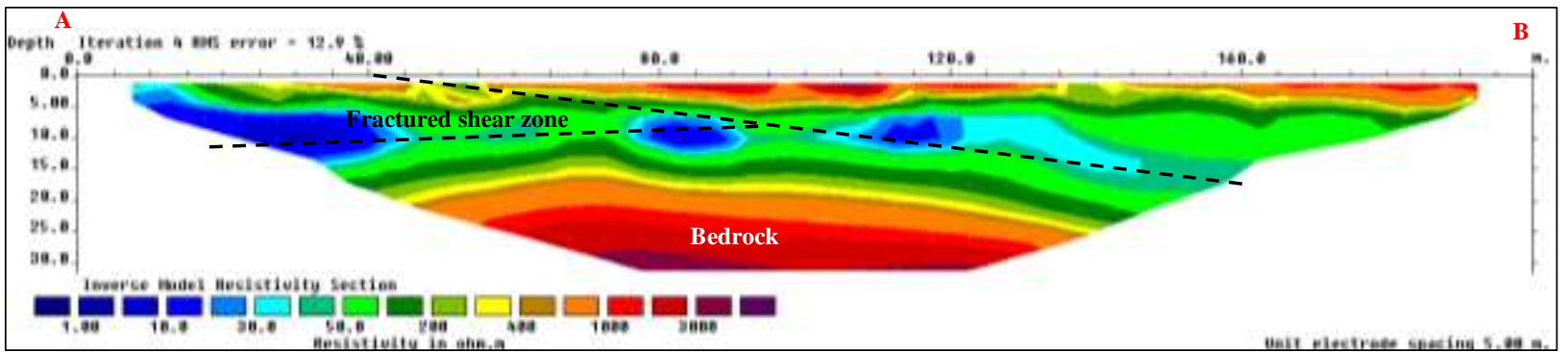

Survey Line 8 in Grid 17

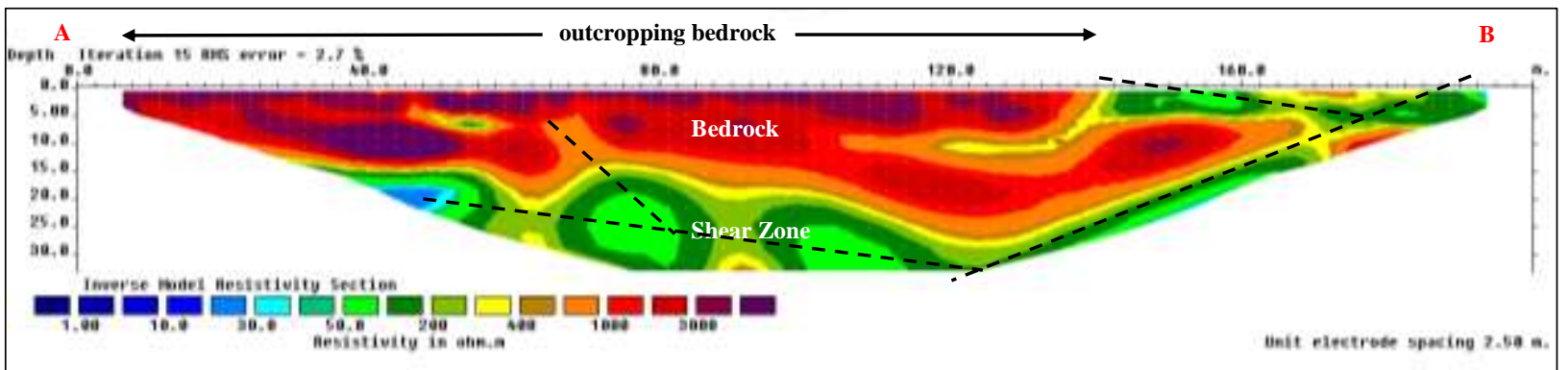

Survey Line 9 in Grid 18 
Gold Potential and Structural Analysis of Bedrock Depth for Sustainable Mining in Batu Melintang, Kelantan

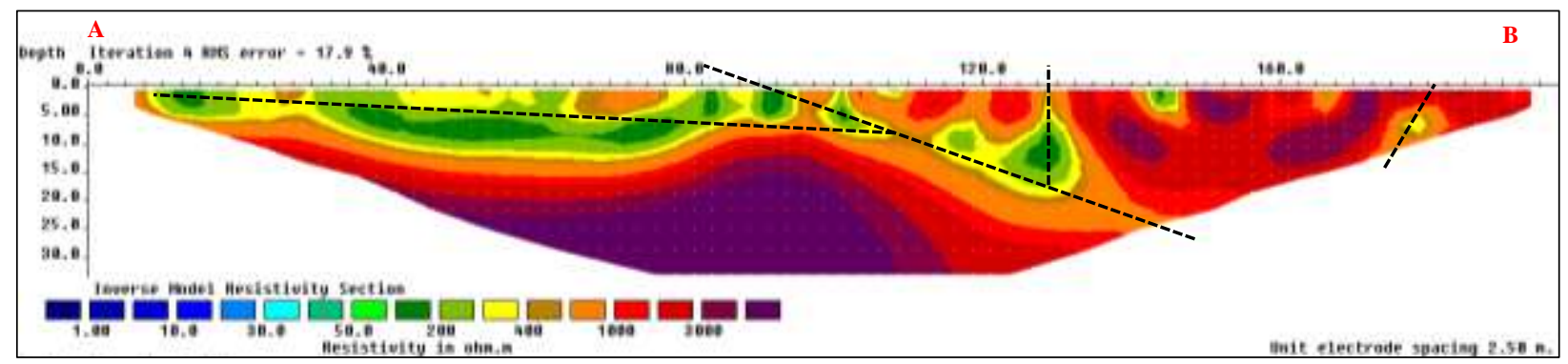

Survey Line 10 in Grid 20 